Canadian Science Publishing

Canadian Journal of Earth Sciences Revue canadienne des sciences de la Terre

\title{
Late Ordovician (Hirnantian) diploporitan fauna of Anticosti Island, Quebec, Canada: implications for evolutionary and biogeographic patterns
}

\begin{tabular}{|r|l|}
\hline Journal: & Canadian Journal of Earth Sciences \\
\hline Manuscript ID & cjes-2017-0160.R1 \\
\hline Manuscript Type: & Article \\
\hline Date Submitted by the Author: & 12 -Oct-2017 \\
\hline $\begin{array}{r}\text { Complete List of Authors: } \\
\text { Is the invited manuscript for } \\
\text { consideration in a Special } \\
\text { Issue? : }\end{array}$ & $\begin{array}{l}\text { Sheffield, Sarah; The University of South Florida, School of Geosciences; } \\
\text { Ausich, William; Department of Geological Sciences } \\
\text { Sumrall, Colin; University of Tennessee, Earth and Planetary Sciences }\end{array}$ \\
\hline Keyword: & Hirnantian, Diploporitan, Echinoderm, Anticosti Island, Ordovician \\
\hline \multicolumn{2}{|c}{} \\
\hline
\end{tabular}




\section{Late Ordovician (Hirnantian) diploporitan fauna of Anticosti}

2 Island, Quebec, Canada: implications for evolutionary and

3 biogeographic patterns

4

$5 \quad$ Sarah L. Sheffield ${ }^{1,2}$, William I. Ausich ${ }^{3}$, and Colin D. Sumrall ${ }^{2}$

6

$7{ }^{1}$ School of Geosciences, The University of South Florida, NES 207, 4202 E. Fowler Ave,

8 Tampa, FL 33620 USA < ssheffield2@usf.edu $>$ ²Department of Earth and Planetary

9 Sciences, University of Tennessee, 602 Strong Hall, 1621 Cumberland Ave, Knoxville,

10 TN, USA $37996{ }^{3}$ School of Earth Sciences, 155 South Oval Mall, The Ohio State

11 University, Columbus, OH 43210 USA < ausich.1@osu.edu> 
22 Abstract: Hirnantian (latest Ordovician) localities containing echinoderm fossils are

23 rare; the few that have been discovered primarily contain disarticulated crinoid ossicles.

24 Therefore, relatively little is known about echinoderm evolutionary dynamics across the

25 Late Ordovician- early Silurian boundary, especially non-crinoid echinoderms. New

26 diploporitan echinoderms, Holocystites salmoensis and an unidentified holocystitid, from

27 reefal facies of the Upper Ordovician Ellis Bay Formation of Anticosti Island provide a

28 critical data point concerning diploporitan biogeography and evolutionary pathways

29 undertaken during the Ordovician and Silurian. These fossils also provide a crucial link in

30 understanding the ancestry of the Silurian Holocystites Fauna, an unusual diploporitan

31 fauna from the middle Silurian of North America, whose origination dates back at least

3215 million years earlier than previously thought with the discovery of taxa described here.

33 New fossil data such as these stress the importance of uncovering new localities from

34 underrepresented times and places in Earth's history, so that these evolutionary

35 transitions can be better understood.

36 Keywords: Diploporitan, Hirnantian, Anticosti Island, Echinoderm, Ordovician. 


\section{Introduction}

The Great Ordovician Biodiversification Event (GOBE) resulted in a significant increase in lower-level diversity across the entire globe, as well as across phyla (Webby et al. 2004). With this large increase in lower-level diversity came an equally dramatic change in substrate and community diversity. Echinoderm biodiversity increased dramatically during the GOBE yielding the peak in class-level richness and peak richness in many echinoderm clades (Guensburg and Sprinkle 2000; Sprinkle and Guensburg 2004; Nardin and Lefebvre 2010; Lefebvre et al., 2013). Then, profound turnover of echinoderm faunas occurred during the Late Ordovician extinctions, the close of the GOBE. Among crinoids, a turnover from the early to the middle Paleozoic Crinoid Evolutionary Fauna occurred (Baumiller 1993; Ausich et al. 1994; Deline and Ausich 2012). Faunas dominated by diplobathrid camerate, disparid, and hybocrinid crinoids were replaced by ones dominated by monobathrid camerate, cladid, and flexible crinoids. Further, other pelmatozoan groups were much more common before than after the Late Ordovician extinctions, although the tempo and fabric of change in non-crinoid echinoderm groups is not as well known. The general lack of complete echinoderm fossils from the latest Ordovician (Hirnantian) to early Silurian has limited our understanding of this critical interval of pelmatozoan evolution.

During the latest Ordovician (Hirnantian), a global regression due to the Hirnantian glaciation reduced accommodation space and promoted subaerial erosion of marine environments, resulting in overall rarer preservation of fossils (Smith 1988; Vennin et al. 
66 1998; Peters and Ausich 2008); echinoderms, whose bodies composed of numerous

67 plates are subject to rapid disarticulation after death (Brett et al. 1997), are no exception

68 to this pattern. The fossil record of most Paleozoic echinoderm groups is very poor in

69 times of global lowstands (Lefebvre et al. 2013). The majority of echinoderm-bearing

70 deposits from the Hirnantian primarily contain disarticulated crinoid ossicles (Donovan

71 1995). Recent discovery of Hirnantian and Rhuddanian crinoids (Eckert 1984; Donovan

72 1993; Fearnhead and Donovan 2007; Ausich and Copper 2010; Ausich et al. 2015;

73 Ausich and Wilson 2016) has improved our understanding of crinoids through this

74 interval (Peters and Ausich 2008; Ausich and Deline 2012). However, relatively little is

75 known about the evolutionary dynamics of non-crinoid echinoderms through the Late

76 Ordovician to early Silurian biodiversity crisis, which makes the discovery of new

77 diploporitan echinoderms from the latest Ordovician of Anticosti Island especially

78 significant. Two species of Holocystites, $H$. salmoensis and $H$. sp., were recently

79 collected from reefal facies in the uppermost Laframboise Member of the Ellis Bay

80 Formation (Hirnantian) of eastern Anticosti Island, Quebec (Fig. 1). These new taxa

81 expand the temporal and biogeographic distribution of diploporitan echinoderms in North

82 America.

83

84

85

86

87

\section{The Holocystites Fauna}

The Holocystites Fauna is an enigmatic grouping of diploporitan echinoderms that, historically, has been restricted to the middle Silurian of North America (with a potential exception of a holocystitid from middle Silurian Australia; see Jell 2011). Whereas this 
88 fauna has been well studied in terms of its systematics (e.g., Paul 1971, Frest et al. 2011, 89 Sheffield and Sumrall 2015, 2017) and taphonomy (e.g., Thomka et al. 2016), very little 90 information about their evolutionary and biogeographical history exists. Paul (1971)

91 suggested the Ordovician Brightonicystis from Baltica, a potential ancestor for the

92 Holocystites Fauna, but this link is tenuous (see Sheffield and Sumrall 2017 for a

93 thorough discussion of Brightonicystis). This lack of information concerning the

94 placement of the Holocystites Fauna in any phylogenetic or biogeographic analysis has

95 hindered our understanding of how this unusual group of Silurian Laurentian

96 diploporitans flourished.

97

98 Morphology of Holocystitids

99 Holocystitids bear a conservative peristomial border-plating pattern (Fig. 2a) and 100 share a specialized type of diplopore respiratory structure (Fig. 3), humatipores (Fig. 3a), 101 that are buried below the surface of the thecal plates and are connected by multiple 102 calcified tangential canals, as opposed to simple diplopores (Fig. 3b; Paul 1972). The 103 peristome is bordered by seven interradially positioned oral plates, with orals 1,6 , and 7 104 contained within the CD interray; O7 is in contact with the periproct. These oral plates 105 are bordered by an open circlet of differentiated plates, facetal plates, which are radially 106 positioned and bear facets for stout appendages (Sheffield and Sumrall 2015, 2017). Taxa 107 within the Holocystites Fauna are differentiated based on modifications to this general 108 plating pattern. Holocystites Hall, 1861 shares the basic plating pattern of all 109 holocystitids, but all members within this taxon are diagnosed by a clockwise rotation of 
110 the ambulacra, which causes the facetal scars to straddle more than one oral plate (Fig.

$1112 \mathrm{~b}$ ); all other holocystitids lack this rotation and facets lie squarely on a single oral plate.

112 Further modifications to taxa within the holocystitids include the loss of certain plates

113 (e.g., non facet bearing facetal plates in Pustulocystis) or the paedomorphic reduction of

114 the A ambulacrum (e.g., Paulicystis and Trematocystis; Sumrall and Wray, 2007). Frest

115 et al. (2011) suggested that more derived taxa within the holocystitids underwent these

116 changes throughout their evolutionary history.

118 Geographic, stratigraphic occurrences, and depositional setting

119 Anticosti Island (Fig. 1) is located in the St. Lawrence Seaway north of the Gaspé

120 Peninsula in Quebec. Approximately $260 \mathrm{~km}$ long and $80 \mathrm{~km}$ wide, Anticosti Island

121 exposes a nearly complete Katian (Ordovician) through Llandovery (Silurian)

122 stratigraphic section of gently dipping strata deposited in a mixed carbonate and

123 siliciclastic setting with periodic reef development (Fig. 3). The Hirnantian (historically

124 post-Cincinnatian Ordovician strata) has been recognized on Anticosti Island since

125 Richardson (1857).

126 The Laframboise Member of the Ellis Bay Formation is uppermost Ordovician

127 (Hirnantian), and the Fox Point Member of the Becscie Formation is lowermost Silurian

128 (Rhuddanian) (Fig. 3). However, the exact Ordovician-Silurian boundary has been a

129 point of major discussion (e.g., Schuchert and Twenhofel 1910; Twenhofel 1928; Bolton

130 1961; Cocks and Copper 1981; Petryk 1981; Long and Copper 1987; Barnes 1988;

131 Copper 1989, 2001; Jin and Copper 2008; Desrochers et al. 2010). Most recently, Copper 
132 et al. (2013) reviewed this aspect of Anticosti Island stratigraphy and they concluded that 133 the megafaunal extinction at the close of the Ordovician occurred coincident with the top 134 of the grainstone facies immediately above the Laframboise reefs (Copper et al. 2013, p. 135 220-222). This grainstone unit may be a few meters thick and represents the earliest, 136 post-reefal transgressive phase during the very latest Ordovician. Uncertainty regarding 137 the Ordovician-Silurian boundary is the result of striking facies changes in this interval 138 across the island from east to west and because many key biostratigraphically important 139 fossil groups are poorly represented in the largely endemic fauna of Anticosti Island (e.g., 140 Barnes 1988; Zhang and Barnes 2002; Melchin 2008).

141 Although the position of the Ellis Bay - Becscie formational boundary in relation to 142 the end-Ordovician extinction horizon remains a topic of discussion (Copper et al. 2013), 143 the stratigraphic position of the Laframboise reefs is certain. The Laframboise Member of 144 the Ellis Bay Formation is from the uppermost Hirnantian, and the reefs are at or very 145 close to the top of this member, thus immediately prior to the Ordovician-Silurian 146 boundary. The farthest reaches of the Hirnantian Laframboise reef horizon, Point 147 Laframboise in the west to the Salmon-Table Head Road in the east (Fig. 2), expose reefs 148 that are no more than approximately 1 to $2 \mathrm{~m}$ in height. The largest reefs (more than $15 \mathrm{~m}$ 149 in height) are exposed along the Salmon River and slightly to the west along the Homard 150 Road.

151 Specimens of Holocystites reported here were collected from the Laframboise 152 Member of the Ellis Bay Formation, Upper Ordovician, uppermost Hirnantian from the 153 outcrop belt on the northern portion of the island (Fig. 4). In this member, 
154 stromatoporoid-coral-calcimicrobial reefs are built up on the eastern part of the Island 155 (Copper 1976, 2001) and they extend discontinuously across Anticosti Island at the same 156 temporal and stratigraphic horizon. The diploporitans described here are from both 157 smaller reefs from a low road cut along the Salmon-Table Head Road, 800 m east of 158 Macaire Creek (UTM: N5469597, E560048) and from large reefs in a road cut along 159 Homard Road, $5.2 \mathrm{~km}$ west of the Salmon River mouth bridge (UTM: N5473856, 160 E5559820). In both instances, diploporitans were collected directly from reef core and 161 reef flank beds.

162 Ausich and Copper (2010) reported twelve crinoid species belonging to ten genera 163 from the Hirnantian of Anticosti Island; however, only six taxa are from the Laframboise 164 Member. Laframboise Member crinoids are all from reef or reef-associated facies. These 165 include Dendrocrinus leptos Ausich and Copper, 2010; Euspirocrinus gangoni Ausich 166 and Copper, 2010; Xenocrinus rubus Ausich and Copper, 2010; Charactocrinus billingsi 167 Ausich and Copper, 2010; Protaxocrinus paraios Ausich and Copper, 2010; and 168 Dimerocrinitid Indeterminate, with only the last three taxa directly associated with the 169 diploporitan taxa described here.

170 The diploporitans reported here are the dominant (based on relative abundance)

171 stalked echinoderms on the Laframboise reefs. Further, diploporitans are absent from 172 older and younger reef horizons on Anticosti Island, such as the Upper Ordovician Katian 173 (Mill Bay Member of the Vauréal Formation) and lower Silurian Aeronian (East Point 174 Member of the Jupiter Formation) reefs (Long and Copper 1994; Copper and Jin 2010). 175 This diploporitan-reef association likely reflects the presence of stabilized substrates 
176 associated with the buildups that are required by the obligate encrusting strategy of 177 Holocystites.

178

179

180 Materials and Methods

181 All specimens are reposited in the Geological Survey of Canada (GSC). This

182 collection comprises 12 thecae, ranging from mostly incomplete (i.e., a few sutured plates

183 preserved) to largely complete. Plate sutures are well preserved on most specimens,

184 although no specimens preserve the holdfast structure and very few preserve the oral

185 area. No specimen preserves the delicate peristomial cover plates or anal cover plates,

186 which is a typical preservation style for diploporitan echinoderms (Sheffield and Sumrall,

187 2017). Analysis of the specimens was done utilizing a microscope and camera lucida.

188 Photographed specimens were whitened with $\mathrm{NH}_{4} \mathrm{Cl}$.

189

190 Systematic paleontology

191 Phylum Echinodermata De Brugière, 1791

192 Subphylum Blastozoa Sprinkle, 1973

193 Class Diploporita Müller, 1854

194 Superfamily Sphaeronitida Neumayr, 1889

195 Family Holocystitidae Miller, 1889

196 Genus Holocystites Hall, 1861

197 Species Holocystites salmoensis, n. sp. 
198 Figs. 5a-e.

199 Holotype: GSC 126899

200 Paratypes: GSC 126897, 126906, 126898,126896, 126908, 126903a, 126903b, 126903c, $201126907,126900,126902$.

202 Etymology: The trivial name means 'salmon' in Greek; these fossils were found along 203 the Salmon River Valley

204 Type Locality: Roadcut along the Salmon-Table Head Road, 800 m east of Macaire 205 Creek (UTM: N5469597, E560048) and from large reefs in a roadcut along Homard 206 Road, $5.2 \mathrm{~km}$ west of the Salmon River mouth bridge.

208 Type Horizon: Ellis Bay Formation, Laframboise Member.

210 Diagnosis: Facetal scars straddle distal edges of oral plate series and facetal plates, 211 positioned on more than one facetal plate. Extra plates between B and C ambulacra, D 212 and E ambulacra, and one proximal to E ambulacra. Relatively squat, globular thecae 213 with tumid plates.

215 Description: Theca globular, relatively squat, with moderate number (30-40) of irregular

216 plates; summit comprised of seven oral plates most proximal to the peristome, seven 217 facetal plates distal to oral plates, and three plates of undetermined origin between the 218 oral and facetal plates (Fig. 5a, c, d); O1, O6, and O7 contained within the CD interray; 219 cover plates not preserved; hydropore not preserved; gonopore circular pore located on 
$220 \mathrm{O} 7$; relatively large periproct in $\mathrm{CD}$ interambulacrum in contact with $\mathrm{O}$, anal pyramid 221 not preserved; single plates bearing humatipores (Fig. 5b) inserted between $\mathrm{O} 4$ and O5, $222 \mathrm{O} 1$ and $\mathrm{O} 2$ and $\mathrm{O} 2$ and $\mathrm{O} 3$; five very short ambulacra present extending from peristome 223 to five facetal scars that straddle distal edge of oral plates and facetal plates; oral plate 224 series rotated slightly clockwise with respect to ambulacra such that food grooves lie atop 225 oral plates rather than along O/O sutures; seven facetal plates in total; elliptical facetal 226 scars relatively large; brachioles, presumably attached to facetal scars in life, are not 227 preserved; thecal plating irregular; plates pentagonal to hexagonal with roughly equal 228 suture lengths, although there is much variation between each plate; plates highly tumid, 229 with centers noticeably raised above deeply depressed sutures (Fig. 5e); new plates added 230 anywhere in theca; humatipores visible where fossil surface has been worn (Fig. 5b);

Remarks: This new species belongs within the larger Holocystites clade based on the numerous humatipores per plate and are evenly spread across surface without a preferred orientation; no humatipores cross plate sutures; theca constricted distally into attachment structure to varying degrees (Fig. 5e), some specimens have more constriction than others; details concerning attachment structure not preserved in available material.

238 species because of the three plates that are neither of oral or facetal plate origin included 239 within the plating of the oral area; no other species of Holocystites has this feature.

240 The new plates, between the B and C ambulacra, the D and E ambulacra, and 241 proximal to the E ambulacra, are thecal plates that are not part of either the oral or facetal 
242 plate series (Fig. 5a, c, d). Their presence does not violate the universal elemental

243 homology scheme of the holocystitids, as discussed in Sheffield and Sumrall (2015,

244 2017) as the plesiomorphic condition of the holocystitids - seven oral plates and seven

245 facetal plates is present. It is likely that these three plates were added late in the

246 ontogenetic series; however, in the absence of well-preserved juvenile fossils, this cannot

247 be examined further.

249 Holocystitidae sp. indet.

250 Material: GSC 126901

$251 \quad$ Fig. $5 f$

252 Description: Theca elongate with a moderate number of irregular plates (15-30); details

253 concerning oral area not preserved in available material; plates flat, with deeply

254 depressed sutures (Fig. 5f); plates of multiple sizes and range from quadrangular to

255 hexagonal; numerous humatipores per plate are evenly spread across surface, although

256 humatipores are largely covered by plate surface and complete humatipores showing both

257 pores are difficult to view; no humatipores cross plate sutures; theca slightly constricted

258 distally into attachment structure; details concerning attachment structure not preserved

259 in available material.

261 Remarks: This specimen can be placed within Holocystitidae based on the presence of

262 humatipore respiratory structures, which are only present within the Holocystites Fauna.

263 However, taxa within the Holocystites Fauna cannot be assigned definitively without 
264 preservation of the oral area; as such, this specimen cannot be further assigned to any 265 particular holocystitid taxon. As the theca and thecal plates are markedly different in 266 makeup from Holocystites salmoensis, it is likely that it is a different species of 267 holocystitid. There is a possibility that this specimen could represent a juvenile 268 ontogenetic sequence of $H$. salmoensis; the specimen is much smaller than the other 269 representatives in the formation and the fewer number of plates in this specimen, as 270 compared with $H$. salmoensis, would be consistent with this idea.

\section{Evolutionary Trends}

273 Based on the diagnosis of Holocystites Hall, 1861 (and modified in Sheffield and 274 Sumrall 2017), it is clear that at least one, and possibly both, of the taxa recently 275 discovered from Upper Ordovician sediments of Anticosti Island belong to the genus 276 Holocystites and certainly belong within the larger Holocystitidae based on the rotation of 277 the ambulacra with respect to the oral plates, facet-bearing facetal plates, and the 278 presence of humatipore respiratory structures. This find extends the range of the 279 holocystitids nearly 15 million years from the middle Silurian (Wenlock) to the Late 280 Ordovician (Hirnantian).

281 Previous studies (e.g., Frest et al. 2011) have suggested that an evolutionary trend 282 within this group was a reduction in the number of plates in the oral area. Although an 283 accurate phylogenetic analysis of the Holocystites Fauna has not been completed (see 284 Sheffield and Sumrall, 2017 for a discussion of previous phylogenetic studies of this 285 fauna), a trend in the reduction of plates within the oral area appears likely and is 
286 corroborated by the oldest example of the Holocystites Fauna, Holocystites salmoensis,

287 having three more plates in the oral area than any Silurian holocystitid. Suspected derived

288 taxa within the Holocystites Fauna (e.g., Pustulocystis) have even further reduction of

289 plates in the oral area, by losing the lateral non-facet bearing facetal plates (Sheffield and

290 Sumrall 2017). It is possible that this reduction of plates in the oral area in Holocystites

291 can be attributed to paedomorphosis. Other taxa within Holocystites, such as Paulicystis

292 and Trematocystis, exhibit paedomorphic reduction of the A ambulacrum and the

293 associated plates (Sumrall and Wray, 2007); however, identifying paedomorphic trends in

294 the fossil record requires a phylogenetic analysis and an understanding of the ontogenetic

295 trends, both of which are beyond the scope of this study.

Biogeographic Implications

298 The discovery of Ordovician-age holocystitid diploporitan fossils has important

299 implications for understanding biogeographic pathways taken by Ordovician

300 echinoderms. Beyond providing further understanding of the relationships of the middle

301 Silurian Holocystites Fauna to Ordovician diploporitans, the discovery of these

302 diploporitan faunas within reefal facies on Anticosti Island suggests that diploporitan

303 echinoderms may have taken similar biogeographic migration pathways to the

304 midcontinental United States as those previously described in other taxa such as

305 brachiopods, trilobites, and some crinoids (e.g., Jin 2001; Ausich and Deline 2012;

306 Wright and Stigall 2013; Bauer and Stigall 2014). These taxa were able to disperse to

307 new basins because of a global sea level rise following the Late Ordovician Boda 
308 Warming Event that lessened basin isolation during the previous lowstand (Fortey and

309 Cocks 2005). This resulted in a dramatic radiation of holocystitids in the North American

310 midcontinent during the middle Silurian where they became locally abundant and diverse

311 members of Wenlock faunas. Presumably, this was achieved by planktonic larvae; while

312 no larval forms of diploporitan fossils are known, and few juvenile fossils known, other

313 echinoderm groups disperse during the larval stage and it is reasonable to assume

314 diploporitans would do the same. It is interesting to note that the east-west migration of

315 diploporitans counters that of crinoids in which the majority of Silurian taxa had roots

316 among Laurentian lineages (Ausich and Deline 2012).

\section{Conclusions}

319 New discoveries from underrepresented times and areas of the world have the 320 potential to change current interpretations of the fossil record. New diploporitan fossils

321 from the Upper Ordovician of Anticosti Island stress the importance of finding these

322 localities to better characterize biogeographic and evolutionary trends. These fossils

323 extend the range of the Holocystites Fauna from solely within the middle Silurian to

324 minimally include the Late Ordovician. The presence of Holocystites from Anticosti

325 Island also suggests that diploporitan echinoderms may have taken similar biogeographic

326 pathways to the middle continent United States as other taxa, such as brachiopods,

327 trilobites, and some crinoids, whose biogeographic pathways from Anticosti Island are

328 better established. 


\section{Acknowledgments}

Fieldwork for this project was conducted with the support to WIA from the National Geographic Society (grant 6789-00) and the National Science Foundation EAR-0205968) P. Copper, J. Jin, and A. Desrochers were stratigraphic and geographic guides during most Anticosti field seasons. The authors would like to thank J. Bauer, A. Lam, and A. Stigall for helpful discussions and S. Zamora and I. Rahman for reviews that improved this manuscript.

\section{References}

Alroy, J. 2008. Dynamics of extinction and origination rates in the fossil record.

Proceedings of the National Academy of Sciences, 105: 11536-11542.

Alroy, J. 2010a. The shifting balance of diversity among major marine animal groups.

Science, 329: 1191-1194.

Alroy, J. 2010b. Geographic, environmental and intrinsic biotic controls on Phanerozoic marine diversifications. Palaeontology, 53: 1211-1235.

Ausich, W.I., and Copper, P. 2001. The Crinoidea of Anticosti Island, Quebéc (Late

Ordovician to Early Silurian). Palaeontographica Canadiana, 29: 157.

Ausich, W.I., and Deline, B. 2012. Macroevolutionary transitions in crinoids following the Late Ordovician extinction event (Ordovician to Early Silurian). Palaeogeography, Palaeoclimatology, Palaeoecology, 361-362: 38-48.

Ausich, W.I., and Wilson, M.A. 2016. Llandovery (early Silurian) crinoids from

Hiiumma Island, western Estonia. Journal of Paleontology, 90: 1139-1147. 
353 Ausich, W.I., Kammer, T.W., and Baumiller, T.K. 1994. Demise of the Middle Paleozoic 354 crinoid fauna. Paleobiology, 20: $345-361$.

355 Ausich, W.I., Peter, M.E., and Ettensohn, F.R. 2015. Echinoderms from the lower

356 Silurian Brassfield Formation of east-central Kentucky. Journal of Paleontology, 89: $357 \quad 245-256$.

358 Barnes, C.R. 1988. Stratigraphy and paleontology of the Ordovician-Silurian boundary 359 interval, Anticosti Island, Quebec, Canada. British Museum Natural History Bulletin 360 (Geology), 43, 195-219.

361 Bauer, J.E., and Stigall, A.L. 2014. Phylogenetic paleobiogeography of Late Ordovician 362 Laurentian brachiopods. Estonian Journal of Earth Sciences, 63, 189-194.

363 Bolton, T.E. 1961. Ordovician and Silurian formations of Anticosti Island, Quebec.

364 Geological Survey of Canada Paper, 71-19, 45.

365 Brett, C.E., Moffat, H.A., and Taylor, W.L. 1997. Echinoderm taphonomy, taphofacies, 366 and Lagerstätten. The Paleontological Society Papers, 3, 147-190.

367 Cocks, L.R.M., and Copper, P. 1981. The Ordovician-Silurian boundary at the eastern 368 end of Anticosti Island. Canadian Journal of Earth Sciences, 18, 1029-1034.

369 Copper, P. 1976. The cyanophyte Wetheredella in Ordovician reef and off-reef 370 sediments. Lethaia, 9, 519-523.

371 Copper, P. 1989. Upper Ordovician and Lower Silurian reefs of Anticosti Island, Quebec.

372 Canadian Society of Petroleum Geologists Memoir, 13, 271-276.

373 Copper, P. 2001. Reefs during the multiple crises towards the Ordovician-Silurian 374 boundary: Anticosti Island, eastern Canada, and worldwide. Canadian Journal of Earth 
375 Sciences, 38, 153-171.

376 Copper, P., and Jin, J. 2010. Early Silurian (Aeronian) East Point coral patch reefs of

377 Anticosti Island, eastern Canada: First reef recovery from the Ordovician/Silurian mass

378 extinction in eastern Laurentian. Geosciences, 2, 64-89.

379 Copper, P., and Jin, J. 2014. The revised Lower Silurian (Rhuddanian) Becscie Formation

380 Anticosti Island, eastern Canada records the tropical marine fauna recovery from the

381 end-Ordovician mass extinction. Newsletters on Stratigraphy, 47, 61-83.

382 Copper, P., Jin, J., Desrochers, A. 2013. The Ordovician-Silurian boundary (late

383 Katian-Hirnantian) of western Anticosti Island: Revised stratigraphy and benthic

384 megafauna correlations. Stratigraphy, 19, 213-227.

385 De Bruguiére, J.G. 1791. Tableau encyclopédique et méthodique des trois règnes de la 386 nature. L'helminthogie, 7, 81p.

387 Desrochers, A., Farley, C., Achab, A., and Asselin, E. 2008. A high-resolution

388 stratigraphic model to resolve the longstanding issues relative to the correlation and

389 interpretation of the O/S boundary on Anticosti Island, Canada. In Palaeozoic climates-

390 International Congress: Closing meeting of the International Geoscience Programme 503

391 "Ordovician Palaeogeography and Palaeoclimate. Edited by B. Kröger and T. Servais.

392 Abstracts, Université of Lille, Lille, p. 32.

393 Desrochers, A., Farley, C., Achab, A., Asselin, E., and Riva, J.F. 2010. A far-field record

394 the end Ordovician glaciations: the Ellis Bay Formation, Anticosti Island, Eastern

395 Canada. Palaeogeography, Palaeoclimatology, Palaeoecology, 296, 248-263.

396 Donovan, S.K. 1993. A Rhuddanian (Silurian, Llandovery) pelmatozoan fauna from 
397 south-west Wales. Geological Journal, 28: 1-19.

398 Donovan, S.K. 1995. No evidence for an echinoderm equivalent of the Hirnantian Fauna.

399 Modern Geology, 20, 11-19.

400 Eckert, J.D. 1984. Early Llandovery crinoids and stelleroids from the Cataract Group

401 (Lower Silurian), southern Ontario, Canada. Royal Ontario Museum Life Sciences

402 Contributions, 137, $83 \mathrm{p}$.

403 Fearnhead, F.E., and Donovan, S.K. 2007. A cladid crinoid (Echinodermata) from the

404 Llandovery (Lower Silurian) of the Girvan district, SW Scotland. Scottish Journal of

405 Geology, 43: 74-82.

406 Fortey, R.M., and Cocks, L.R.M. 2005. Late Ordovician global warming-the Boda event.

407 Geology, 33, 405-408.

408 Hall, J. 1861. Descriptions of new species of fossils: from the investigations of the

409 survey. Report of the Superintendent of the Geological Survey Exhibiting the Progress of

410 the Work. Madison, Wisconsin, 9-52.

411 James, N.P., Desrochers, A., and Kyser, T.K. 2015. Polygenic (polyphase) karsted

412 hardground omission surfaces in lower Silurian neritic limestones: Anticosti Island,

413 eastern Canada. Journal of Sedimentary Research, 85, 1139-1154.

414 Jell, P.A. 2011. Late Silurian echinoderms from the Yass Basin, New South Wales-the

415 earliest holothurian body fossil and two diploporitan cystoids (Sphaeronitidae and

416 Holocystitidae). Australasian Palaeontological Society Memoirs, 39, 29-41. 
417 Jin, J. 2001. Evolution and extinction of the North American Hiscobeccus brachiopod 418 Fauna during the Late Ordovician. Canadian Journal of Earth Sciences, 38, 143-151.

419 Jin, J., and Copper, P. 2008. Response of brachiopod communities to environmental 420 change during the Late Ordovician mass extinction interval, Anticosti Island, Eastern 421 Canada. Fossils and Strata, 54, 41-51.

422 Lefebvre, B., Sumrall, C.D., Shroat-Lewis, R.A., Reich, M., Webster, G.D., Hunter, 423 A.W., Nardin, E., Rozhnov, S.V., Guensberg, T.E., and Touzeau, A. 2013.

424 Palaeobiogeography of Ordovician echinoderms. Geological Society, London, Memoirs, 425 38, 173-198.

426 Long, D.G.F., and Copper, P. 1987. Stratigraphy of the Upper Ordovician upper Vauréal 427 and Ellis Bay formations, eastern Anticosti Island, Québec. Canadian Journal of Earth 428 Sciences, 24, 1807-1820.

429 Long, D.G.F., and Copper, P. 1994. The late Ordovician-early Silurian carbonate tract of 430 Anticosti Island, Gulf of St. Lawrence, eastern Canada. Geological Association of 431 Canada, Mineralogical Association of Canada, Joint Annual Meeting, 1994, Waterloo, 432 Ontario, Canada Field Trip B4 Guidebook, 1-69.

433 Melchin , M.J. 2008. Restudy of some Ordovician-Silurian boundary graptolites from 434 Anticosti Island, Canada, and their biostratigraphic significance. Lethaia, 41, 155-162. 435 Miller, S.A., North American geology and paleontology. Western Methodist Book 436 Concern, Cincinnati, $\mathrm{OH}$.

437 Müller, J. 1854. Über den Bau der Echinodermen. Königlichen Preussische Akademie 438 der Wissenschaft, Abhandlungen, 1853, 125-220. 
439 Neumayr, M. 1889. Die Stämme des Thierreiches. Wirbellose Thiere, Vienna and $440 \quad$ Prague, 603p.

441 Peters, S. E., and Ausich, W. I. 2008. A sampling-adjusted macroevolutionary history for 442 Ordovician-Early Silurian crinoids. Paleobiology, 34, 104-116.

443 Petryk, A.A. 1981. Stratigraphy, sedimentology, and paleogeography of the Upper 444 Ordovician-Lower Silurian of Anticosti Island, Québec. In Subcommission on Silurian 445 stratigraphy, Ordovician-Silurian Boundary Working Group. Edited by P.J. Lespérance.

446 Field meeting Anticosti-Gaspé, Québec, Université de Montréal, 2, pp. 10-39.

447 Richardson, J. 1857. Report of the year 1956. Canadian Survey of Canada Report of 448 Progress for the years 1853-54-55-56, 191-245.

449 Schuchert, C., and Twenhofel, W.H. 1910. Ordovicic-Siluric section of the Mignan and 450 Anticosti islands, Gulf of St. Lawrence. Geological Society of America Bulletin, 21, $451 \quad 677-716$.

452 Smith, A. B. 1988. Fossil evidence for the relationships of extant echinoderm classes and 453 their times of divergence. In Echinoderm Phylogeny and Evolutionary Biology. Edited by 454 Paul, C.R.C. and Smith, A.B. Clarendon Press, Oxford, pp. 85-106.

455 Sprinkle, J. 1973. Blastozoan echinoderms. Harvard University Museum of Comparative 456 Zoology Special Publication, 283.

457 Sepkoski, J.J. Jr. 1996. Patterns of Phanerozoic extinction: a perspective from global 458 databases. In Global events and event stratigraphy in the Phamerozoic. Edited by O.H. 459 Walliser. Springer-Verlag, Berlin, pp. 31-51

460 Sheffield, S.L., and Sumrall, C.D. 2015. A new interpretation of the oralplating patterns 
461 of the Holocystites fauna. In Progress in Echinoderm Palaeobiology. Edited by S. Zamora

462 and I. Rábano. Instituto Geológico y Minero de España, Cuademos del Museo

463 Geominero, 19, pp. 159-162.

464 Sheffield, S.L., and Sumrall, C.D. 2017. Generic revision of the Holocystitidae of North

465 America (Diploporita, Echinodermata) based on universal elemental homology. Journal

466 of Paleontology, 91, 755-766.

467 Sumrall, C.D., and Wray, G.A. 2007. Ontogeny in the fossil record: diversification of

468 body plans and the evolution of "aberrant" symmetry in Paleozoic echinoderms.

469 Paleobiology, 33, 149-163.

470 Twenhofel, W.H. 1928. Geology of Anticosti Island. Geological Survey of Canada

471 Memoirs, 154, 481..

472 Vennin, E., Alvaro, J.J., and Villas, E. 1998. High-latitude pelmatozoan-bryozoan

473 mud-mounds from the late Ordovician northern Gondwanan platform. Geological

474 Journal, 33, 121-140.

475 Webby, G.D., Paris, F., Droser, M.L., and Percival, I.G. 2004. The Great Ordovician

476 Biodiversification Event. Columbia University Press, New York, NY, 484 p.

477 Wright, D.F., and Stigall, A.L. 2013. Geologic drivers of Late Ordovician faunal change

478 in Laurentia: investigating links between tectonics, speciation, and biotic invasions. PLoS

479 One, 8, e68353.

480 Zhang, S., and Barnes, C.R. 2002. A new Llandovery (Early Silurian) conodont

481 biozonation and conodonts from the Becscie, Merrimack, and Gun River formations,

482 Anticosti Island, Québec. Paleontological Society Memoir, 76, 1-46. 
$483 \quad$ Figures

484 Figure 1. General map of study area. A. Anticosti Island's position within the larger

485 Canadian region (modified from James et al. 2015). B. Map of the eastern portion of

486 Anticosti Island, with ranges of Ellis Bay Formation marked in gray. Areas from which

487 the diploporitan fossils were collected are marked with white circles.

488 Figure 2. Plating patterns of holocystitids. A. Typical border plating patterns for all

489 holocystitid taxa; seven oral plates surround the peristome (M); O1, O6, and $\mathrm{O} 7$

490 contained within the CD interray. O7 is in contact with the periproct (P). Facetal plates

491 distal to oral plates; five of these facetal plates bear facet scars for ambulacra.

492 Modifications to this general pattern delineate the different taxa within the Holocystites

493 Fauna. B. Genus Holocystites is diagnosed by the rotation of ambulacra so that the facetal

494 scars straddle the sutures of more than one oral plate. Modified from Sheffield and

495 Sumrall, 2017.

496 Figure 3. Diagrammatic representation of diploporitan respiratory structures. A.

497 Humatipores are a modified form of a diplopore respiratory structure; the two pores are

498 connected by multiple, calcified canals and are not situated within a peripore.

499 Humatipores are buried beneath the surface of the thecal plate and are only visible when

500 a thecal plate has been weathered. B. Simple diplopores, formed in pairs, are situated in a

501 shallow depression (the peripore) that sits on a thecal plate. The canal connecting the two

502 pores is not calcified and is, therefore, not preserved. Light gray=peripore; dark grey=

503 pore openings; medium gray= calcified canals.

504 Figure 4. Generalized stratigraphic section of the Ordovician-Silurian boundary reef 
505 section in eastern Anticosti Island. Thickness of the reef interval is variable, and the exact 506 position of the Ordovician-Silurian boundary is a point of discussion, as noted. The 507 lowest bed of the Laframboise Member contains abundant oncolites. Stratigraphic and 508 corresponding chronostratigraphic units are given.

509 Figure 5. Diploporitans from Anticosti Island. A. Oral area of Holocystites salmoensis; 510 oval peristome surrounded by six oral plates; $\mathrm{O} 7$ is precluded from the oral plate circlet 511 by $\mathrm{O} 5$ and $\mathrm{O6}$; five facets resting on oral plates; facetal plates surrounding oral plate 512 series, with three extra plates, of neither facetal nor oral plate origin, contained within 513 this system. View of tumid thecal plates and humatipore respiratory structures also 514 visible; side view of specimen largely prevented due to matrix (GSC 126899). B. Close 515 up view of humatipores of $H$. salmoensis. Note the scroll pattern of the tangential canals.

516 As humatipores are buried below the surface of the thecal plate, completely exposed 517 humatipore respiratory structures are not often exposed (GSC 126899). C. Line drawing 518 of Holocystites salmoensis. White= facetal plates; light gray= oral plates; dark gray= 519 non-oral or facetal plates; $\mathrm{M}=$ peristome; $\mathrm{P}=$ periproct; black circle= gonopore $(\mathrm{GSC}$ 520 126899). D. Oral view of $H$. salmoensis with periproct preserved; periproct, round, in 521 contact with O7; side view of specimen largely prevented due to matrix (GSC 126897). 522 E. Side view of $H$. salmoensis, showing tumid and irregular thecal plates; plates are not 523 weathered, so there is an absence of visible humatipores. Theca narrows considerably 524 distally. Oral area not preserved (GSC 126906). F. Side view of unidentified holocystitid 525 with flat thecal plates. Specimen considerably smaller than other examples collected. 526 Oral area not preserved (GSC 126901). Scale bar $=1 \mathrm{~cm}$. Specimens whitened with $\mathrm{NH}_{4} \mathrm{Cl}$. 


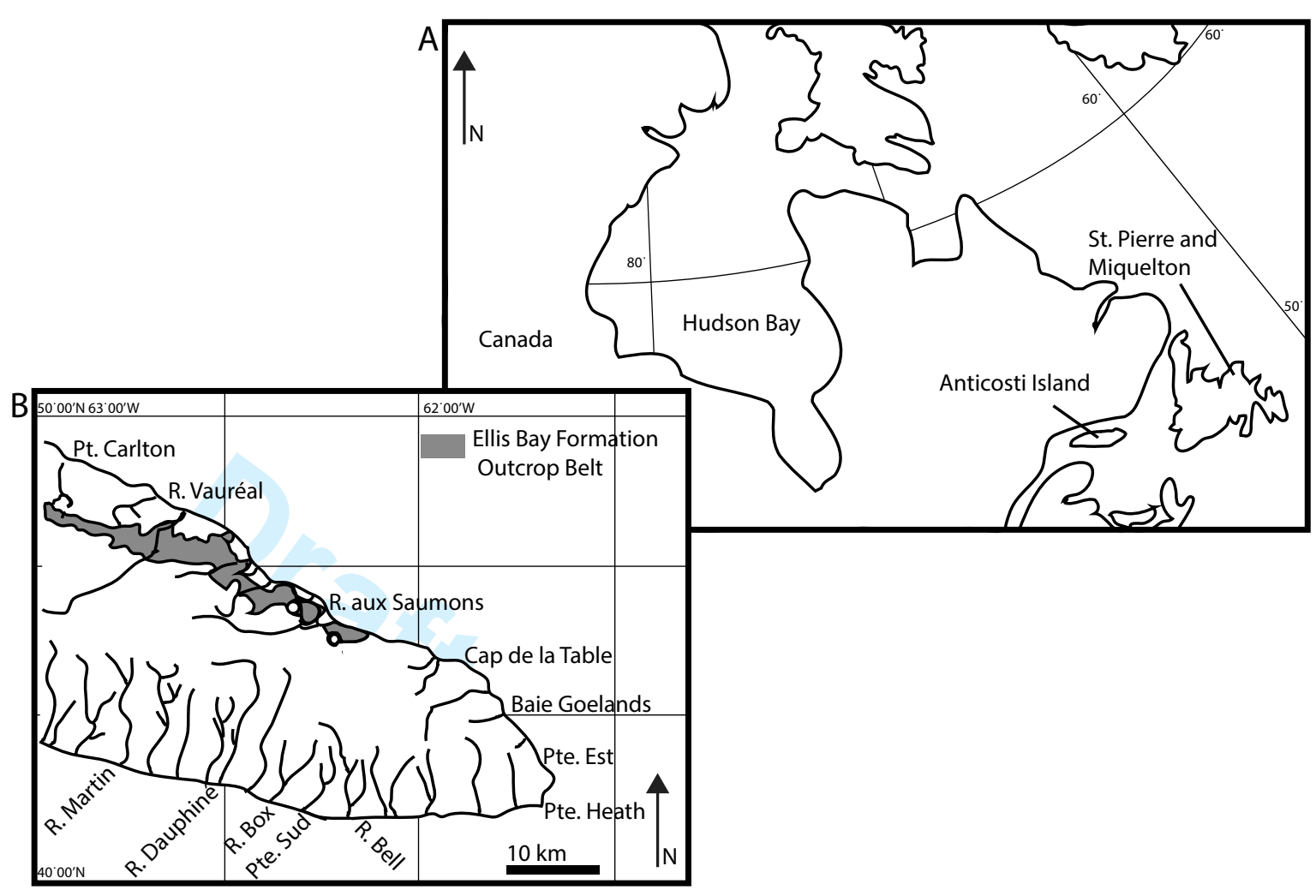


9 


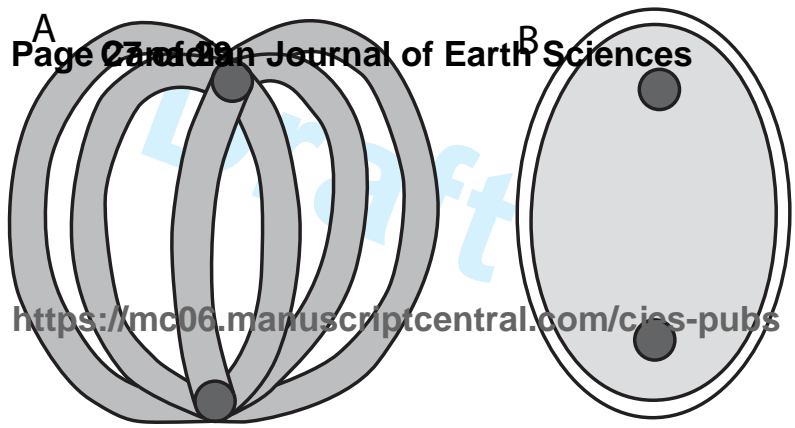




\section{Canadian Journal of Earth Scien 28 of 29}

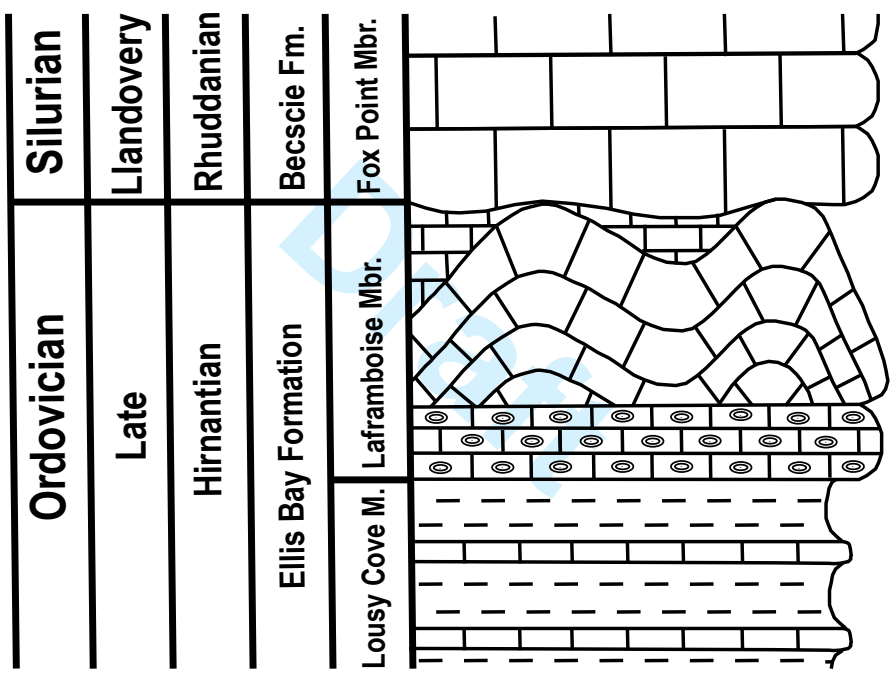

https://mc06.manuscriptcentral.com/cjes-pubs 


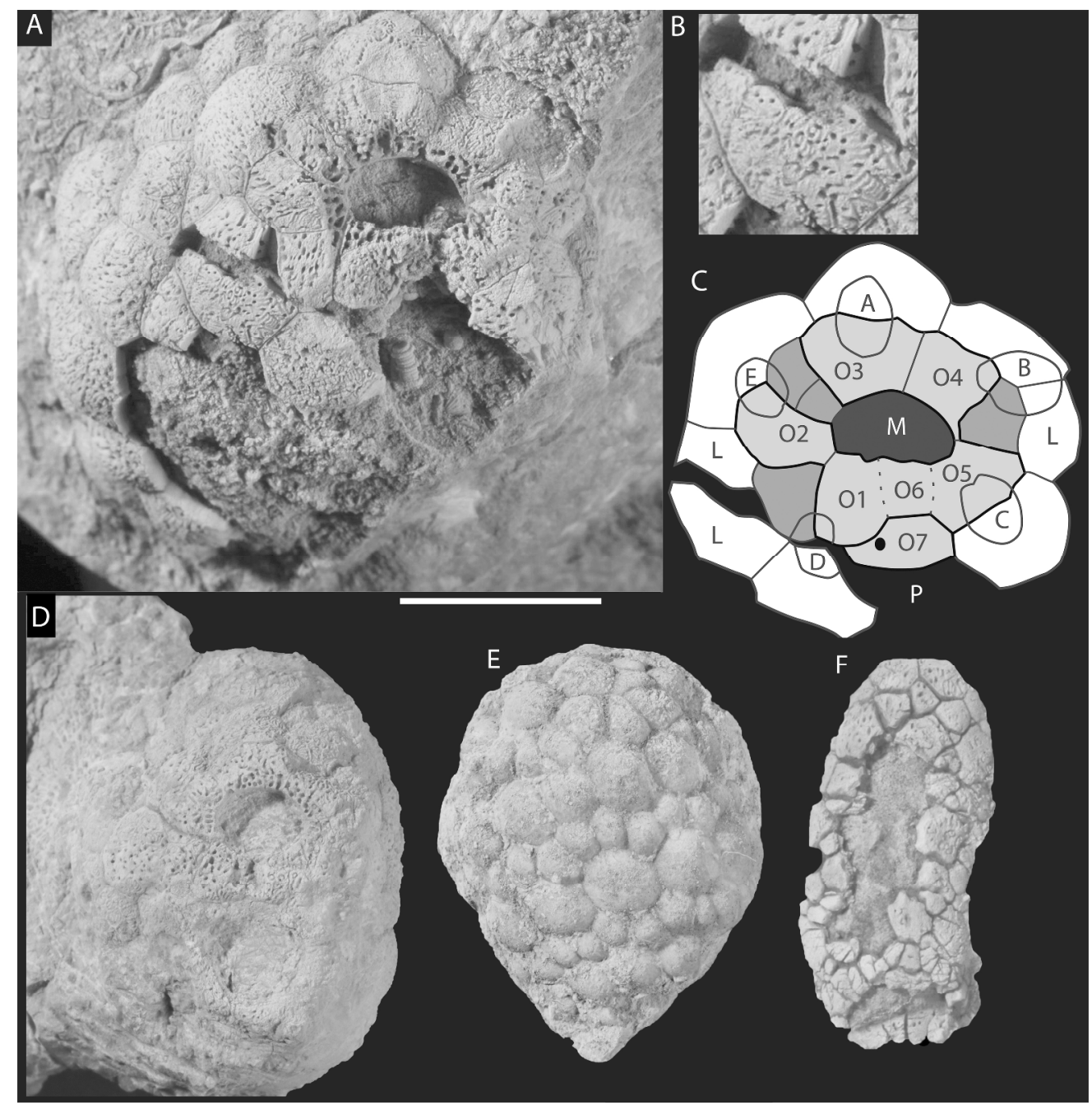

Figure 5. Diploporitans from Anticosti Island. A. Oral area of Holocystites salmoensis; oval peristome surrounded by six oral plates; 07 is precluded from the oral plate circlet by 05 and 06 ; five facets resting on oral plates; facetal plates surrounding oral plate series, with three extra plates, of neither facetal nor oral plate origin, contained within this system. View of tumid thecal plates and humatipore respiratory structures also visible; side view of specimen largely prevented due to matrix (GSC 126899). B. Close up view of humatipores of $\mathrm{H}$. salmoensis. Note the scroll pattern of the tangential canals. As humatipores are buried below the surface of the thecal plate, completely exposed humatipore respiratory structures are not often exposed (GSC 126899). C. Line drawing of Holocystites salmoensis. White= facetal plates; light gray= oral plates; dark gray= non-oral or facetal plates; $M=$ peristome; $\mathrm{P}=$ periproct; black circle= gonopore (GSC 126899). D. Oral view of $H$. salmoensis with periproct preserved; periproct, round, in contact with 07; side view of specimen largely prevented due to matrix (GSC 126897). E. Side view of $H$. salmoensis, showing tumid and irregular thecal plates; plates are not weathered, so there is an absence of visible humatipores. Theca narrows considerably distally. Oral area not preserved (GSC 126906). F. Side view of unidentified holocystitid with flat thecal plates. Specimen considerably smaller than other examples collected. Oral area not preserved (GSC 126901). Scale bar $=1 \mathrm{~cm}$. Specimens whitened with $\mathrm{NH} 4 \mathrm{Cl}$. 